(c) American Dairy Science Association, 2004.

\title{
Feed Efficiency of Mid-Lactation Dairy Cows Fed Yeast Culture During Summer*
}

\author{
D. J. Schingoethe, ${ }^{1}$ K. N. Linke, ${ }^{1}$ K. F. Kalscheur, ${ }^{1}$ A. R. Hippen, ${ }^{1}$ \\ D. R. Rennich, ${ }^{1}$ and I. Yoon ${ }^{2}$ \\ ${ }^{1}$ Dairy Science Department, South Dakota State University, Brookings 57007-0647 \\ 2Diamond V Mills, Inc., Cedar Rapids, IA 52401
}

\begin{abstract}
Thirty-eight Holstein cows (26 multiparous and 12 primiparous), that averaged $105 \mathrm{~d}$ postpartum at the start of the experiment, were used to evaluate the feeding of yeast culture (60 g/cow daily of Diamond V XP) on production efficiency during hot summer weather. From early June until early September and after a 2-wk covariate period, cows were fed a control diet without or with $60 \mathrm{~g}$ of yeast culture/cow daily for $12 \mathrm{wk}$. Weekly daytime high temperatures in the free-stall barn during the 12 -wk period averaged $33^{\circ} \mathrm{C}\left(28\right.$ to $\left.39^{\circ} \mathrm{C}\right)$. Total mixed diets on a dry matter (DM) basis consisted of corn silage (28\%), alfalfa hay (21\%), and a concentrate mix $(51 \%)$ without or with the yeast culture added to the total mixed ration at the time of feeding. Milk production ( 34.9 and $35.4 \mathrm{~kg} / \mathrm{d}$, for control and yeast culture treatment, respectively), $4 \%$ fat-corrected milk (31.2 and $32.0 \mathrm{~kg} / \mathrm{d}$ ), energy-corrected milk (ECM; 33.4 and $34.2 \mathrm{~kg} / \mathrm{d}$ ), and DM intake (23.1 and $22.1 \mathrm{~kg} / \mathrm{d}$ ) were similar for cows fed control and yeast culture diets. Percentages of milk fat (3.34 and 3.41) and true protein (2.85 and 2.87) were similar for both diets. Feed efficiency defined as kilogram of ECM/kilogram of DM intake was improved by $7 \%$ for cows fed the yeast culture. Body weights and body condition scores were similar for both groups. The results suggest that the yeast culture can improve feed efficiency of heat stressed dairy cows in midlactation.
\end{abstract}

(Key words: yeast culture, lactating cows, feed efficiency)

\section{Abbreviation key: ECM = energy-corrected milk. \\ INTRODUCTION}

Yeast and yeast cultures have been fed to dairy cattle for more than $60 \mathrm{yr}$ with varied responses. In some

\footnotetext{
Received July 14, 2004.

Accepted September 17, 2004.

Corresponding author: D. J. Schingoethe; e-mail: david. schingoethe@sdstate.edu.

*Published with the approval of director of the South Dakota Agricultural Experiment Station as Publication Number 3403 of the Journal Series.
}

studies, yeast cultures improved DMI (Williams et al., 1991; Wohlt et al., 1991; Dann et al., 2000) and milk production (Williams et al., 1991; Wohlt et al., 1991; Piva et al., 1993; Wang et al., 2001), whereas other studies (Erdman and Sharma, 1989; Arambel and Kent, 1990; Soder and Holden, 1999) found no response to yeast cultures. Wohlt et al. (1991) suggested that supplementing yeast culture before parturition and extending through peak lactation was necessary to evaluate the effect on lactating cows. Some field reports indicate increased DMI and milk production when yeast was fed during periods of heat stress, possibly reflecting the role in aiding appetite during time of stress (Huber, 1998); however, controlled scientific studies to substantiate such claims are lacking. There are reports that a culture of Aspergillus oryzae in diets of lactating cows increased milk production, feed efficiency, and tolerance to heat stress in some (Gomez-Alarcon et al., 1990) but not all (Higginbotham et al., 1993; Yu et al., 1997) studies. Such a product may have somewhat similar affects on ruminal fermentation and digestibility as might be expected to occur with yeast culture.

Improvements in feed efficiency can positively impact herd profitability even when changes in production or feed intake or both may be very slight (Britt et al., 2003; Casper et al., 2003). If feeding yeast culture can cause even modest improvements in ruminal fermentation and digestibility and minimize heat stress, improvements in feed efficiency may occur. The objective of this study was to evaluate the use of yeast culture in diets of lactating dairy cows, especially during times of heat stress.

\section{MATERIALS AND METHODS}

All procedures in this study were conducted under approval of the South Dakota State University Animal Care and Use Committee. Thirty-eight Holstein cows (26 multiparous and 12 primiparous) that averaged 105 DIM (SD $=28 \mathrm{~d}$ ) were used to evaluate yeast culture added to the diet. Cows were paired based on DIM, parity (first or second and later lactations), and pretreatment milk production. One cow from each pair 
Table 1. Ingredient content of diets. ${ }^{1}$

\begin{tabular}{lc}
\hline Ingredient & \% of DM \\
\hline Alfalfa hay & 21.0 \\
Corn silage & 28.0 \\
Corn, ground shelled & 19.3 \\
Whole cottonseed & 8.0 \\
Soybean meal, 44\% CP & 8.8 \\
Dried distillers grains with solubles & 7.7 \\
Pork meat and bone meal & 1.3 \\
Fish meal, menhaden & 0.3 \\
Energizer 4-19 W ${ }^{2}$ & 2.5 \\
Megalac & 0.9 \\
Limestone & 0.7 \\
Sodium bicarbonate & 0.5 \\
Salt & 0.5 \\
MgO & 0.15 \\
Trace mineral/vitamin premix & 4 \\
Zinpro 4-plex &
\end{tabular}

${ }^{1}$ Yeast culture diet contained $60 \mathrm{~g} / \mathrm{cow}$ daily of Diamond V XP yeast culture (Cedar Rapids, IA) added at the time of feeding.

${ }^{2}$ Quality Liquid Feeds Mfg., Inc., Dodgeville, WI; 4\% CP and 19\% fat, as-fed basis.

${ }^{3}$ Church and Dwight, Inc., Princeton, NJ.

${ }^{4} \mathrm{Mg}, 10.0 \%$; Zn, 2.6\%; Mn, 1.7\%; Fe, 4640 ppm; Cu, 4712 ppm; I, 398 ppm; Co, 119 ppm; Se, 140 ppm; vitamin A, 544,000 IU/kg; vitamin D, 109,000 IU/kg; vitamin E, 2177 IU/kg.

${ }^{5}$ Zinpro Corp., Eden Prairie, MN.

${ }^{6}$ Contained 44,000 IU/kg.

was randomly assigned to control or yeast culture diet (Diamond V XP yeast culture, Cedar Rapids, IA; $60 \mathrm{~g} /$ cow daily added to the TMR at the time of feeding). Total mixed diets (Table 1) on a DM basis were corn silage $(28 \%)$, alfalfa hay $(21 \%)$, and concentrate mix $(51 \%)$ with or without yeast culture. Diets were formulated to meet or exceed NRC requirements (NRC, 2001).

Cows were housed in the northwest pen of a 4-pen curtained free-stall barn for 160 cows. The barn contained 91-cm diameter fans over the feeding alleys every $15 \mathrm{~m}$ and misters over the feeding alleys that were operated according to temperature to aid in cooling during hot weather. Cows were fed individually using Calan Broadbent feeder doors (American Calan, Inc., Northwood, NH). Cows were placed in the free-stall area and assigned to Calan feeding doors 2 wk before the start of the 12-wk experiment. The 12-wk experimental period was from June 12 to September 3, 2002. Milk yield, milk composition, and feed intake data during the 2-wk pretreatment period were used for covariate adjustment of data. Cows were individually fed the respective TMR once daily at $1000 \mathrm{~h}$ for ad libitum consumption with continuous access to feed except during milking. Amounts fed and refused were recorded daily.

Cows were milked daily at 0600,1400 , and $2100 \mathrm{~h}$. Milk was sampled from all 3 milkings during $1 \mathrm{~d}$ each wk, and daily composites were analyzed for fat, protein, lactose, and total solids (AOAC, 1997) by midinfrared spectrophotometry (Multispec; Foss Food Technology Corp., Eden Prairie, MN); SCC (AOAC, 1997) was determined using a Fossomatic 90 (Foss Food Technology Corp.).

Samples of alfalfa hay, corn silage, cottonseed, concentrate mixes, and TMR were collected weekly and stored at $-20^{\circ} \mathrm{C}$ until analyses. As-fed formulations of TMR were adjusted weekly, if necessary, to account for changes in DM content of corn silage determined by microwave oven. Weekly samples were dried at $55^{\circ} \mathrm{C}$ in a Despatch oven (style V-23, Despatch Oven Co., Minneapolis, MN) for $48 \mathrm{~h}$, then ground through a 2mm screen of a standard Wiley mill (model 3, Arthur H. Thomas Co., Philadelphia, PA) and composited by 4-wk periods. Composites were analyzed for CP, ether extract, ash, $\mathrm{Ca}, \mathrm{P}, \mathrm{Mg}$, and $\mathrm{K}$ according to AOAC (1997) methods. Neutral detergent fiber (procedure B of VanSoest et al., 1991) and ADF (Robertson and VanSoest, 1981) were determined by ANKOM fiber analyzer with the fiber bag technique (ANKOM Technology Corp., Fairport, NY). Body weights were recorded twice during the covariate period and weekly throughout the trial. Body condition scores (Wildman et al., 1982) were determined by 3 independent observers at the end of the covariate period and at $\mathrm{d} 28,56$, and 84 of the experimental period.

Temperatures were recorded daily at 0600 and 1400 $h$ in the center of the curtained free-stall barn at times the cows were being moved to the holding pen for milking. Data from the South Dakota State University weather station located $3.3 \mathrm{~km}$ from the barn were used for evaluation of environmental temperature conditions (South Dakota Climate and Weather, 2003; http://climate.sdstate.edu/climate_site/climate.htm).

Data were analyzed using the mixed procedures of SAS (SAS Institute, 1996). Fixed effects were treatment, pair, parity, week, and treatment $\times$ week. Random effects were cow within pair. Repeated measures within cow were analyzed using the first-order autoregression structure. In general, inclusion of the covariate period in the model did not make a difference in treatment means or standard errors, so it was dropped from the model. Model effects were considered significant at $P<0.05$ with trends noted at $P<0.20$.

\section{RESULTS AND DISCUSSION}

The nutrient composition of the diets (Table 2) was as expected except for $\mathrm{Ca}, \mathrm{P}$, and $\mathrm{Mg}$, which were slightly higher than anticipated. These differences were due to higher concentrations than estimated in the alfalfa hay.

Dry matter intake, milk yield, and milk composition (Table 3) were similar with or without yeast culture in 
Table 2. Nutrient content of forages and TMR.

\begin{tabular}{|c|c|c|c|}
\hline Nutrient & $\begin{array}{l}\text { Corn } \\
\text { silage }\end{array}$ & $\begin{array}{l}\text { Alfalfa } \\
\text { hay }\end{array}$ & TMR \\
\hline Dry matter, $\%$ & 30.4 & 82.6 & 56.8 \\
\hline $\mathrm{CP}$ & 7.9 & 20.5 & 17.5 \\
\hline $\mathrm{NE}_{\mathrm{L}},{ }^{1} \mathrm{Mcal} / \mathrm{kg}$ & 1.52 & 1.47 & 1.78 \\
\hline Fat & 2.9 & 1.4 & 5.3 \\
\hline $\mathrm{NDF}$ & 49.7 & 36.6 & 30.8 \\
\hline $\mathrm{ADF}$ & 29.7 & 31.0 & 20.2 \\
\hline $\mathrm{Ca}$ & 0.26 & 1.49 & 1.15 \\
\hline $\mathrm{P}$ & 0.24 & 0.28 & 0.50 \\
\hline $\mathrm{Mg}$ & 0.24 & 0.43 & 0.39 \\
\hline $\mathrm{K}$ & 0.94 & 1.61 & 1.12 \\
\hline
\end{tabular}

${ }^{1}$ Estimated from NRC (2001).

the diet. Body weights and BCS were similar with or without yeast culture in the diet. All of the above parameters differed by week $(P<0.01)$ except for SCC $(P=0.62)$. As expected, some parameters differed by parity, but no treatment $\times$ parity interactions approached significance. Treatment $\times$ week interactions were not different $(P>0.15)$.

The objective of this experiment was to evaluate the effects of feeding yeast culture to cows during times of heat stress. Temperatures (average of daily highs and lows) averaged $22^{\circ} \mathrm{C}, 2^{\circ} \mathrm{C}$ higher than the 72 -yr average for the time span of the experiment (http://climate.sdstate.edu/climate_site/climate.htm). Although temperatures averaged the same in the free-stall barn as recorded at the weather station, daytime high temperatures were higher in the barn $\left(\right.$ mean $=32.7^{\circ} \mathrm{C}$ vs. $28.3^{\circ} \mathrm{C}$ at the weather station). The weather station reported

Table 3. Milk yield and composition, DMI, BW, and BCS.

\begin{tabular}{|c|c|c|c|c|}
\hline \multirow[b]{2}{*}{ Item } & \multicolumn{2}{|c|}{ Diet } & \multirow[b]{2}{*}{$\mathrm{SE}$} & \multirow[b]{2}{*}{$P$} \\
\hline & Control & Yeast & & \\
\hline Milk, kg/d & 34.9 & 35.4 & 1.13 & 0.75 \\
\hline $4 \% \mathrm{FCM}, \mathrm{kg} / \mathrm{d}$ & 31.2 & 32.0 & 1.23 & 0.64 \\
\hline $\mathrm{ECM},{ }^{1} \mathrm{~kg} / \mathrm{d}$ & 33.4 & 34.2 & 1.24 & 0.62 \\
\hline \multicolumn{5}{|l|}{ Milk components } \\
\hline \multicolumn{5}{|l|}{ Fat, } \\
\hline$\%$ & 3.34 & 3.41 & 0.09 & 0.57 \\
\hline $\mathrm{kg} / \mathrm{d}$ & 1.16 & 1.21 & 0.05 & 0.49 \\
\hline \multicolumn{5}{|l|}{ Protein, } \\
\hline$\%$ & 2.85 & 2.87 & 0.04 & 0.57 \\
\hline $\mathrm{kg} / \mathrm{d}$ & 0.98 & 1.01 & 0.04 & 0.72 \\
\hline \multicolumn{5}{|l|}{ Lactose, } \\
\hline$\%$ & 4.83 & 4.80 & 0.03 & 0.36 \\
\hline $\mathrm{kg} / \mathrm{d}$ & 1.66 & 1.69 & 0.06 & 0.76 \\
\hline $\mathrm{SCC}, \times 10^{3} / \mathrm{mL}$ & 166 & 492 & 218 & 0.27 \\
\hline DMI, kg/d & 23.1 & 22.1 & 0.82 & 0.38 \\
\hline FCM/DMI & 1.39 & 1.49 & 0.03 & 0.04 \\
\hline ECM/DMI & 1.49 & 1.59 & 0.03 & 0.04 \\
\hline BW, kg & 629 & 616 & 9.9 & 0.34 \\
\hline BCS & 3.00 & 3.04 & 0.10 & 0.77 \\
\hline
\end{tabular}

${ }^{1} \mathrm{ECM}=$ Energy-corrected milk.
$21 \mathrm{~d}$ with high temperatures greater than $32^{\circ} \mathrm{C}$ (with all of those days occurring during wk 2 to 8 of the experiment), whereas the barn had $51 \mathrm{~d}$ when the temperature exceeded $32^{\circ} \mathrm{C}$. The greater variation in temperatures within the barn vs. at the weather station was likely because the barn is located in a more open area whereas the weather station is on the edge of the university campus. Even with cooling enhancements such as $91-\mathrm{cm}$ diameter fans every $15 \mathrm{~m}$ and misters over the feeding areas, there were days when cows showed signs of heat stress such as decreased feed intake and lack of movement. For weeks with the highest temperatures (i.e., wk 2 to 8), milk yield (34.6 and 35.1 $\mathrm{kg} / \mathrm{d})$ and DMI (22.5 and $21.2 \mathrm{~kg} / \mathrm{d}$ for all cows decreased relative to the overall experimental treatment means shown in Table 3. However, analysis of changes in feed intake and milk production data around such "heat stress" days did not show any statistically detectable differences in response to the presence or absence of yeast culture in the diet.

Feed efficiency, as indicated by production of FCM and energy-corrected milk (ECM) per kilogram of feed DM consumed, was higher $(P<0.05)$ when yeast culture was fed. This improvement in feed efficiency reflected slight trends $(P=0.25$ and 0.16 , respectively, for FCM and ECM) toward higher production coupled with a trend $(P=0.16)$ toward lower DMI when fed yeast culture. However, the treatment $\times$ week interactions for the 2 feed efficiency calculations were not significant $(P>0.92)$, and there was no indication of greater differences between treatments during the weeks of hottest weather. Admittedly, temperatures during the entire experiment, especially daytime temperatures, were all above the thermoneutral zone for cattle (McDowell, 1981); therefore, separating a response between hot vs. cool weather was not possible in this experiment. These results tended to support field reports and results (Huber, 1998; Yoon et al., 2003) that indicated tendencies for improved response of lactating cattle when fed yeast culture.

The mode of action by which the feeding of yeast culture may improve feed efficiency of heat-stressed dairy cows is not known. Improved appetite during heat stress has been proposed (Huber, 1998), but is not substantiated by our data. Improved ration digestibility (Gomez-Alarcon et al., 1990) is another possible explanation, but diet digestibilities were not evaluated in our study.

\section{CONCLUSIONS}

Supplementing yeast culture in the diet of heatstressed dairy cows can improve feed efficiency. Changes in milk production and DMI intake during 
times of heat stress were very subtle and not statistically significant.

\section{ACKNOWLEDGMENTS}

We thank the employees of the South Dakota State University Dairy Research Facility for care of the cows and Valley Queen Cheese Factory, Milbank, SD, for milk analysis. This research was partially supported by funding from Diamond V Mills, Inc., Cedar Rapids, IA.

\section{REFERENCES}

Arambel, M. J., and B. A. Kent. 1990. Effect of yeast culture on nutrient digestibility and milk yield response in early to midlactation dairy cows. J. Dairy Sci. 73:1560-1563.

Association of Official Analytical Chemists. 1997. Official Methods of Analysis. 16th ed. AOAC Intl., Gaithersburg, MD.

Britt, J. S., R. C. Thomas, N. C. Spear, and M. B. Hall. 2003. Efficiency of converting nutrient dry matter to milk in Holstein herds. J. Dairy Sci. 86:3796-3801.

Casper, D. P., L. A. Whitlock, D. Schauff, and D. Jones. 2003. Consider the intake/efficiency trade-off. Hoard's Dairyman 148:604.

Dann, H. M., J. K. Drackley, G. M. McCoy, M. F. Hutjens, and J. E. Garrett. 2000. Effects of yeast culture (Saccharomyces cerevisiae) on prepartum and postpartum intake and milk production of Jersey cows. J. Dairy Sci. 83:123-127.

Erdman, R. A., and B. K. Sharma. 1989. Effect of yeast culture and sodium bicarbonate on milk yield and composition in dairy cows. J. Dairy Sci. 72:1929-1932.

Gomez-Alarcon, R. A., C. Dudas, and J. T. Huber. 1990. Influence of Aspergillus oryzae on rumen and total tract digestion of dietary components. J. Dairy Sci. 73:703-710.

Higginbotham, G. E., D. L. Bath, and L. J. Butler. 1993. Effect of feeding Aspergillus oryzae extract on milk production and related responses in a commercial dairy herd. J. Dairy Sci. 76:1484-1489.

Huber, J. T. 1998. Yeast products help cattle handle heat. Hoard's Dairyman 143:367.

McDowell, R. 1981. Page 79 in Effect of Environment on the Nutrient Requirements of Domestic Animals. Natl. Res. Council, Natl. Acad. Press, Washington, DC.
National Research Council. 2001. Nutrient Requirements of Dairy Cattle. 7th rev. ed. Natl. Acad. Press, Washington, DC.

Piva, G., S. Belladonna, G. Fusconi, and F. Sichaldi. 1993. Effects of yeast on dairy cow performance, ruminal fermentation, blood components, and milk manufacturing properties. J. Dairy Sci. 76:2717-2722.

Robertson, J. B., and P. J. VanSoest. 1981. The detergent system of analysis and its application to human foods. Pages 123-129 in The Analysis of Dietary Fiber. W. P. T. James and O. Theander, ed. Marcel Dekker, New York, NY.

SAS Institute. 1996. SAS/STAT Software. Changes and enhancements through release 6.12. SAS Inst., Inc., Cary, NC.

Soder, K. J., and L. A. Holden. 1999. Dry matter intake and milk yield and composition of cows fed yeast prepartum and postpartum. J. Dairy Sci. 82:605-610.

South Dakota Climate and Weather. 2003. South Dakota State University, Brookings. Online. Available: http://climate.sdstate.edu/ climate_site/climate.htm. Accessed Oct. 5, 2004.

VanSoest, P. J., J. B. Robertson, and B. A. Lewis. 1991. Methods for dietary fiber, neutral detergent fiber, and nonstarch polysaccharides in relation to animal nutrition. J. Dairy Sci. 74:3583-3597.

Wang, Z., M. L. Eastridge, and X. Qiu. 2001. Effects of forage neutral detergent fiber and yeast culture on performance of cows during early lactation. J. Dairy Sci. 84:204-212.

Wildman, E. E., G. M. Jones, P. E. Wagner, R. L. Bowman, H. F. Trout, and T. N. Lesch. 1982. Dairy cows body condition score and its relationship to selected production characteristics. J. Dairy Sci. 65:495-501.

Williams, P. E. V., C. A. G. Tait, G. M. Innes, and C. J. Newbold. 1991. Effects of the inclusion of yeast culture (Saccharomyces cerevisiae plus growth medium) in the diet of dairy cows on milk yield and forage degradation and fermentation patterns in the rumen of steers. J. Anim. Sci. 69:3016-3026.

Wohlt, J. E., A. D. Finkelstein, and C. H. Chung. 1991. Yeast culture to improve intake, nutrient digestibility, and performance by dairy cattle during early lactation. J. Dairy Sci. 74:1395-1400.

Yoon, I., G. M. Kamande, C. R. Belknap, M. A. Engstrom, and M. A. Kujaiva. 2003. The role of yeast culture in transition cow nutrition. J. Dairy Sci. 86:3803.

Yu, P., J. T. Huber, C. B. Theurer, K. H. Chen, L. G. Nussio, and Z. Wu. 1997. Effect of steam-flaked or steam-rolled corn with or without Aspergillus oryzae in the diet on performance of dairy cows fed during hot weather. J. Dairy Sci. 80:3293-3297. 